\title{
Labour Ideologies and Labour Relations in Colonial Portuguese America, I 500-1700*
}

\author{
TARCISIO R. B OTELHO \\ Department of History, Universidade Federal de Minas Gerais \\ E-mail: tbotelho@fafich.ufmg.br
}

Summary: During the two first centuries of Portuguese colonization in America there was an intense debate about the legitimacy of enslaving Africans and Indians. In Portuguese America, the mission to spread the Christian faith was connected with the subjection of populations on both sides of the Atlantic Ocean to an ideology that considered labour as God's punishment for Adam's sin. In that sense, the justification of the unfree labour inflicted upon Indians and Africans in Portuguese America was a product of the same ideology, one that condemned manual work as rendering a man dishonourable. The purpose of this article is to review the debate from its medieval origins in Portugal, and to examine what effect the arrival of the Jesuits in America had on that debate, until the final prohibition of Indian enslavement in the mid-eighteenth century, documented by letters, reports, and sermons.

\section{INTRODUCTION}

This article aims to discuss labour ideologies in Portuguese America during the sixteenth and seventeenth centuries in connection with changes to labour relations. It adopts the definitions of the Global Collaboratory on the History of Labour Relations, which divides the workforce into three major groups: "commodified labour" (working for the market or for non-market institutions, self-employed, employers, chattel slaves); "reciprocal labour" (housewives, dependants); and "tributary labour" (forced labour, serfs). Looking at the transformations in labour relations during the initial two centuries of Portuguese colonization in America, we can see two major changes: first, the widespread use of commodified labour, and second, the

\footnotetext{
* I should like to acknowledge the financial support of CNPq (National Council for Scientific and Technological Development, Brazil, grant number \#310248/2007-8) and FAPEMIG (Research Support Foundation of Minas Gerais State, Brazil, grant number \#PPM-00334/2008), and also to thank Christine Moll-Murata, Karin Hofmeester, and Douglas Cole Libby for their comments on earlier versions of this article, David Lopez for his help with the map, and Litany Ribeiro Pires for help in translating from the Portuguese.
} 
predominance of chattel slavery at a time when, in Europe, free labour was becoming the most important labour relation.

The widespread use of slavery in connection with production for the market defined the history of Portuguese America. During the sixteenth century, the establishment of sugar mills polarized colonial society into masters and slaves. Between those two poles other forms of labour relation could be found; though less important and subordinate, they were present to a varying extent in the workforce. First, there was an increasing proportion of self-employed and independent producers such as farmers and peasants, craftsmen, specialized workers, and the like, who were free workers dedicated to commodified labour for the market. Second, the Indians were organized into small villages (aldeamentos) controlled by religious orders, especially the Jesuits; they may be regarded as workers subject to reciprocal labour within their communities. From the second half of the seventeenth century until the eighteenth, aldeamentos declined in number and importance while free labour increased along with the expansion of sugar mills, farms, and cattle ranches.

Labour ideologies were profoundly influenced by that process. Medieval ideologies of social organization were very important in the establishment of a social orientation to the master's ideal of honour. On the other hand, we can find some discourses on Indians and slaves that reinforced the disqualification of manual work - "to work with one's own hands" - as God's punishment for sin. To discuss all these topics, I shall start by describing the formation of colonial Portuguese America, with a discussion about the colonization process and how the population submitted to the Portuguese colonists. After that, I shall discuss ideological views of the work of masters ("the nobility of the land") and slaves ("the hands and feet of the sugar-mill master”).

\section{THE FORMATION OF COLONIAL PORTUGUESE AMERICA}

The initial Portuguese colonization of America included a period of exploitation and the establishment of feitoria houses that extended from I 500 , when the first Portuguese fleet arrived in Porto Seguro, to the I 530 . The presence of an autochthonous population and the greater interest of the Portuguese in trading with Asia justified their adoption of an unstable form of occupation, which resulted in the settlement of a small number of Europeans, mainly men. It followed naturally that families were formed with indigenous women, given that such was the only opportunity for "domestic" life that the Portuguese men had at the time.

Colonization of a permanent nature started in I 530 with the arrival of expeditions which brought the first people willing to settle on the land. The institution of an inheritable captaincy system was intended to encourage permanent settlement, with the Portuguese Crown's current 
interest in Asia as the predominant factor. Before I550, only the captaincies of São Vicente and Pernambuco could be regarded as successful, while in Santo Amaro, Espírito Santo, Porto Seguro, Ilhéus, and Itamaracá success was marginal. São Tomé, Bahia, and Maranhão had failed dismally, while the other five captaincies remained unexplored.

The I 540 s saw a crisis unleashed by the reaction of the indigenous population to permanent occupation. Along with threats of invasion by other European maritime powers, the recently founded colony was on the brink of collapse. Given the steady loss of its monopoly over Asian commerce, the Portuguese government decided to adopt a stricter policy for America, and so in I 549 a general government was established, led by Tomé de Sousa from I 549 to I 553 , which spared no effort to overcome the pervasive instability that the colony was experiencing. The first three general governments managed to reverse the situation, and by about I 570 , at the end of Mem de Sás government, it is possible to conclude that Portuguese colonization in America had been consolidated.

From that point on, the colony saw the expansion of sugar-cane plantations, which began to cover larger areas in the Zona da Mata in the north-east, from Bahia to Rio Grande do Norte. Later, activity expanded to the south, finding in Campos, Rio de Janeiro, a particularly suitable area for the cultivation of sugar cane. During the seventeenth century regions such as Maranhão and Pará were occupied, as were Santa Catarina and Rio Grande closer to the turn of the eighteenth century. In the last decade of the seventeenth century and the first decades of the eighteenth century, the discovery of gold and diamonds brought exploration and the definitive incorporation of the interior of the American continent.

It is, however, important to note that the sugar industry was the basis of Portuguese settlement in Brazil, and that the engenho, which means sugar mill but, by extension, sugar plantation too, embodied much more than just agricultural exploitation. In fact, it constituted the nucleus of Brazilian colonial society at least until the end of the seventeenth century, and the crucial role of the engenho in Brazilian society is a central theme of Brazilian historiography. From the colonial chronicles until the arrival of traditional historiography at the beginning of the twentieth century and the modern historiography of the last few decades there has been a long tradition of studying the Brazilian sugar industry. ${ }^{\mathrm{I}}$ Even after the development of a gold-mining society in Minas Gerais, and the progressive diversification

I. See, for example, Pero de Magalhães Gândavo, Tratado da terra do Brasil: Historia da provincia Santa Cruz (Belo Horizonte, I980); Gabriel Soares de Sousa, Noticia do Brasil (São Paulo, I974); Gilberto Freyre, Casa-grande e senzala (Rio de Janeiro, I933); Stuart Schwartz, Sugar Plantations in the Formation of Brazilian Society: Babia, I550-I835 (Cambridge, 1985); and Luiz Felipe de Alencastro, O trato dos viventes: formação do Brasil no Atlântico Sul, séculos XVI e XVII (São Paulo, 200I). 
of the colonial economy at the end of eighteenth century, colonial social organization was continuously influenced by the relationship between masters and slaves that had initially been built up in the engenho.

In this process of establishing a stable colonial society in Brazil, the crucial problem to be solved was that of the labour force. As Stuart Schwartz emphasized, since its Mediterranean experience the sugar-cane economy had been characterized by relatively large land units, welldeveloped long-range commerce, and enslaved or coerced labour. ${ }^{2}$ Use of the Indian population was the first option tried by the senhores de engenho (sugar planters). When the Portuguese arrived in this part of America, they found none of the complex pre-Colombian state organizations, such as those which confronted the Spanish, first in Meso-America and later in the central Andes. There was also a much lower demographic density and attendant scattering throughout the territory. What followed the arrival of the Portuguese was a process of acculturation of these people, achieved by means of the villages organized by the Jesuits and a few other religious groups, and enslavement.

The clustering of Indians in villages first started on the coast, after the adoption by Portugal of a more effective colonization policy. In I 549, the first Governor-General, Tomé de Sousa, brought Jesuits with him, whom he put in charge of contacting and organizing the indigenous population in what would become one of the vectors of the process of their incorporation into the Portuguese colonization project. The villages saw stagnation, success, and failure until the I570s, in the midst of a decline in the indigenous population, when they were dispersed throughout more extensive territories. By the end of the seventeenth century, the various religious orders were administering villages in places as far apart as the Amazon and the extreme south of the Portuguese colony in America. In the second half of eighteenth century, the villages were the subject of a dispute due to the new policies adopted by Marquês de Pombal, the main minister of the Portuguese Crown, in his administration of the Portuguese overseas empire.

The other tactic for incorporating the indigenous population into Portuguese America was enslavement. Added to the cultural conflicts, the initial attempts of early colonizers were complicated by the demographic crisis of the I540S, which resulted from the sum of a number of factors, including wars, epidemics, and famine. From i 560 and the Caetés War, the numbers of Indians living on the coast and in neighbouring areas diminished. From then on, the supply of indigenous slaves dwindled steadily too, and there was more incentive to send expeditions further and further inland.

The advance of Portuguese colonization based on the expansion of sugar production and the steady decrease in the indigenous populations 


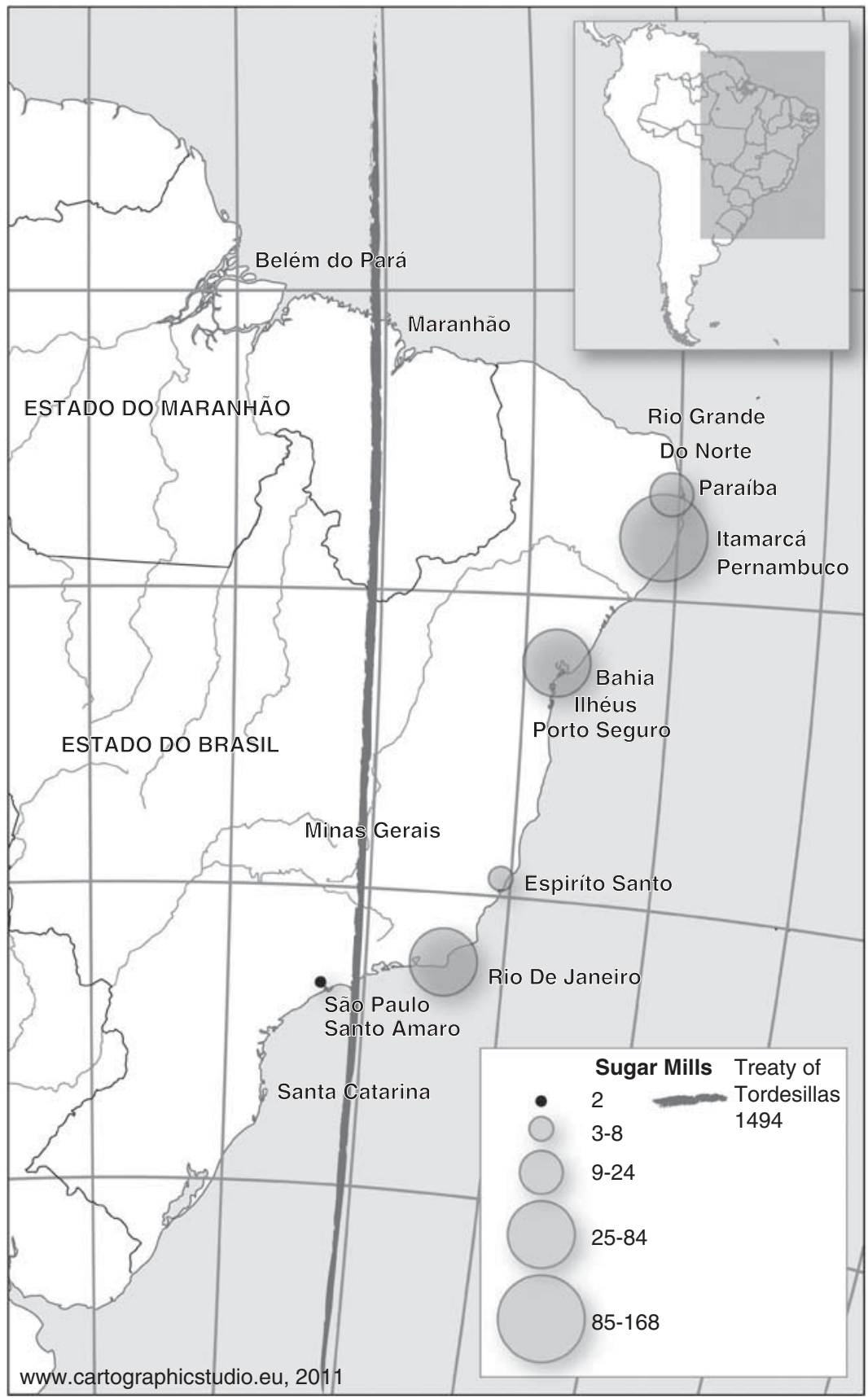

Figure I. Sugar mills in Brazil in I629.

Frédéric Mauro, Portugal, o Brasil e o Atlântico, I570-1670 (Lisbon, 1997), p. 255. 
made the option of African slavery quite feasible. At the turn of the sixteenth century, although Indian slaves remained an important source of labour on plantations African slaves appeared to be the best option for meeting the needs of a rapidly expanding sugar economy. Growing demand led to the consolidation of the slave trade across the Atlantic, ${ }^{3}$ and by the mid-seventeenth century Africans predominated in the slave population, while Indians represented a residual segment and became restricted to the economic periphery of the colony. At the same time, the Jesuits and other religious orders continued to organize the indigenous people into newly established aldeamentos under a labour relation I will describe as reciprocal labour within their communities.

We do not know precisely when the first Africans arrived in Brazil, but there were already substantial numbers of them at the beginning of the I 540 s. Pero de Magalhães Gândavo, a colonial chronicler, calculated a total of 2,000 to 3,000 black people in Brazil in 1570 , and in 1587 the Jesuit priest, José de Anchieta, mentioned I4,000 in his letters. ${ }^{4}$ Estimates for the slave trade have been relatively well studied by several researchers. Herbert Klein synthesized the data to show a total of 50,000 slaves arriving on Portuguese-American shores in the sixteenth century (I530-1600), 560,000 in the seventeenth century, I.68 million in the eighteenth century, and 1.72 million in the nineteenth century up to 1852.5

In terms of the stock of slaves at different times during colonization, there remains the problem of a simple lack of information, with estimates less precise, being based mainly on informed guesswork. More reliable estimates for the period until the end of the seventeenth century were produced by Contrera Rodrigues, in $1935 .{ }^{6} \mathrm{He}$ mentions a total population of over 100,000 in 1600 and of 184,000 in 1660 . Of that 100,000 , there might have been 30,000 white people and 70,000 mixed race, black, and Indian in 1600; by 1660 , the number of white people and free Indians had reached 74,000 , and that of slaves i I0,000. In I690, the population might have been over 242,000 , but there is no information on its composition.

The sugar mill took a central role in the colonial economy, becoming the nucleus upon which colonial society was organized. It retained its indisputable position until the beginning of the eighteenth century, when

3. An excellent description of the "African option" can be found in Schwartz, Sugar Plantations, Part I.

4. H.B. Johnson, "A colonização portuguesa no Brasil, I 500-I 580 ", in Leslie Bethell (ed.), História da América Latina, Volume I: América Latina colonial (São Paulo, 1998), pp. 24 I-28 I, 268.

5. Herbert Klein, "Tráfico de escravos", in FIBGE, Estatísticas históricas do Brasil (Rio de Janeiro, I990), pp. 53-61, 60.

6. These estimates were synthesized in Clotilde Andrade Paiva, José Alberto Magno de Carvalho, and Valéria da Motta Leite, "Demografia", in FIBGE, Estatisticas históricas do Brasil, pp. I9-52, 30 . 
gold deposits discovered in the interior of Portuguese America started competing for primacy. It is estimated that by I630 inhabitants of sugarproducing areas amounted to more than three-quarters of the total population of Portuguese America. In those areas more than two-thirds of the population was enslaved, and although there was a significant proportion of free people working in sugar mills (I estimate it at less than 20 per cent of the total labour force) slavery was the predominant labour relation. ${ }^{7}$

Although there were other important social categories within colonial society, the central role played by the sugar-based economy gave rise to the basic polarity between masters and slaves. Therefore, in order to understand the work ethics prevailing throughout the Brazilian colonial period it is necessary to understand the values and norms orientating those two poles: the sugar-mill masters, on the one hand, and the slaves on the other. In the case of the slaves, it is important to highlight the division between Indians and Africans in the sixteenth and seventeenth centuries, a division that came to an end only in the eighteenth century.

\section{THE SUGAR-MILL MASTERS, OR THE NOBILITY OF THE LAND}

In their transplantation to America, the Portuguese brought with them notions of social hierarchy firmly rooted in the ideas of a society that had inherited medieval principles. Because of that, the work-related values and norms that prevailed throughout the Brazilian colonial period are best approached by first looking at their medieval Iberian heritage.

At the end of the eleventh century, social stability was considered the absolute organizing principle of Portuguese society. In Portugal, as in the rest of medieval western Europe, the representation of society was regarded as the prime social ordering system, within the tradition of IndoEuropean society in general. At the beginning of the eleventh century Adalberón de Laon developed the classic tripartite division of society: oratores, bellatores, and laboratores. ${ }^{8}$ In other words, the organization of society was based on its division into the clergy, the nobility, and the people, each of which were conscious of their duties and performed their functions in harmony.

In Portugal, until the end of the thirteenth century the terms used to refer to the nobility or the class of masters expressed the idea of "the one that holds power" rather than "the warrior". In that sense it came down to

7. These estimates are included in an unpublished paper presented to the Fifth Workshop of the Global Collaboratory on the History of Labour Relations, I500-2000, Düsseldorf, I 2-I4 November 2009 .

8. Jacques Le Goff, Time, Work, and Culture in the Middle Ages (Chicago, IL, I98I), p. 53; see also Georges Duby, The Three Orders: Fendal Society Imagined (Chicago, IL, I98I). 
"the capacity to manage, administer, and command". 9 Therefore the privileges of the nobility included not only the appropriation of assets, but also ways of exerting power over men: "exerting public authority, judging, commanding warriors, collecting taxes, enforcing the law". ${ }^{\text {Io }}$ Those deprived of such privileges were dependent on the nobility and had no alternative but to subject themselves to it. They were the dependants whose prerogatives were limited to the possession of their own bodies and land, and that is why they dedicated themselves to productive activities. Thus, they were the laboratores. At that time, dependants were divided into distinct categories of worker: inheritors, settlers, commission agents (butlers, judges, and leaseholders), wage-earners, and other fringe categories such as hunters or fishermen. Work was a mark of those on the lowest rungs of society.

In the fourteenth and fifteenth centuries, Portuguese society was still conceived within that model, but political, economic, and social transformations started to appear in social interactions, both within the existing orders and between them. According to José Mattoso, "the prerequisite of this hierarchical social-political inequality, co-natural to the image of the society of orders, expanded within each one of them. In other words, it encroached upon the inner parts of the third [order] and strengthened itself in the second [order]." "I The influence of mobile wealth, in other words money, started to be felt in all states. In the fifteenth century, "the rule of the quantitative, the appeal of the century, allures all: kings, noblemen, clergymen, bourgeoisie, and artisans. They all rely on money to be and to go up, but all of them dismiss it as tarnishing. Divided minds, ambivalent attitudes." ${ }^{2}$

In that series of transformations, the townspeople started to form a cluster of occupations and professions. The criteria of wealth, prestige, and power set them apart as "good men" (or bourgeoisie), artisans, manual workers, and servants. Their segment invaded the fringes of the clergy and the nobility, especially the king's vassals, the usurping noblemen, shield-men, and bourgeois knights. But people still defined themselves by their work. Work was equated with suffering, the result of the punishment of Adam, who, because of his sin, had to toil to get his sustenance. Only farming had some value, since it provided people with their food. However, as businesses, services, and handicrafts developed, cities began producing wealth, which was increasingly becoming the key to power. Steadily, the concept that divided society into three orders ebbed away.

At the end of the Middle Ages, it makes more sense to say that Portuguese society was organized into "estates". Although it still thought of itself as a

9. José Mattoso, História de Portugal, II (Lisbon, I993), p. 176.

Iо. Ibid, p. 197.

I I. Ibid., p. 396.

I 2. Ibid., p. $42 \mathrm{I}$. 
society of orders (which implied a much more rigid conception of society), in this new society of "estates" occupations, codes, and professions now defined social status. In that sense, "knowledge and wealth, or personal and familial success, become more relevant as the real propellers of social mobility, supplanting attributes that had customarily been exclusively inherited". ${ }^{3}$ The colonists of Portuguese America therefore brought with them these concepts of society.

As society was based on agriculture, it inherited social principles that tended to value that type of work. Sugar planting, in turn, favoured the consolidation of a pattern of behaviour compatible with the ideal of the nobility, especially when it came to creating a long roll of dependants. Social hierarchization played an essential role in the order of social life. Stuart Schwartz mentions a letter by Duarte Coelho, donatary of the captaincy of Pernambuco, in which the occupations of his settlers were described. ${ }^{14}$ At the top of the list came the sugar-mill masters. They were in charge of directing operations, and were made even nobler as they controlled the work of freemen as well as of slaves, who were their dependants. Then came the sugar-cane farmers, dependants to varying degrees on the owners of the sugar plantations, which was where their cane was milled. Cane farmers aspired to become sugar-mill owners too, and that motivated a small degree of social mobility, especially among whites. The men dedicated to the production of food for local consumption were regarded as being similar to European peasants, and for that reason they were respected since they were essential to everyone. After them were mentioned the merchants and artisans. Slaves did not feature in the description, despite the fact that they formed the majority of the inhabitants.

In that social order then, sugar-mill masters were at the apex of a pyramid. In 1629 there were 346 sugar mills in Brazil, some of which were owned by religious orders. ${ }^{\text {Is }}$ If it is assumed that each mill-owning family had 6 members, about 2,000 people were at the top of the pyramid, of a total population estimated at i 56,800 inhabitants.

The ideal of nobility would dictate performance and behavioural patterns. In the absence of noble blood, a nobleman was defined in the colony by what it was not fitting for him to do: he should never do manual work, own a shop, make crafts, nor perform any less noble occupation. Ideally, his income would come from rents or public office. Everyone aspired to the titles, status, and privileges of the aristocracy. Climbing up the rungs of the social ladder meant a person would first be elevated to the status of a nobleman, which was granted to the first-born, to those able to boast

14. Schwartz, Sugar Plantations, p. 26.

I 5. Mauro, Portugal, o Brasil e o Atlântico, p. 255. 
some military rank, and those holding attitudes and values cultivated by the sugar-plantation masters. In their society, the first conquerors and their descendants occupied a special place, calling themselves the "noble families" or the "nobility of the Republic". ${ }^{16}$

Such noblemen would spend their lives without doing any manual work, as that would have been considered demeaning. The presence of Indians and Africans made every European into a potential "good man". As a result, new social distinctions were created which were based on culture and skin colour. According to Schwartz, the connections established between origin and/or colour, on the one hand, and the internal structure of property and the labour force, on the other, "reinforced the social hierarchy and reaffirmed the gradations in a practical and demonstrable way. The engenho [sugar mill] was both mirror and metaphor of Brazilian society." 7

The quest for wealth in the colony allowed migrant groups to embrace profitable activities, which also provided them with attributes belonging to the status of nobility, at least in the colonial context. Cristãos Novos (or New Christians, converted Jews and their descendants) and some members of the commercial bourgeoisie, two groups considered inferior by Portuguese society, were commonly found among the sugar-mill masters, but that did not prevent them, as a class, from seeing themselves as the nobility of the land. Later on, people born in Brazil joined such immigrants and their children. Throughout Brazilian colonial history, however, the sugar-mill masters sought to consolidate themselves as a colonial nobility by means of functions, actions, and lifestyle. The process proved contradictory because, according to Schwartz, "the successful pursuit of wealth in the context of this tropical colony upset Portuguese hierarchies of status, race, and wealth and created a series of negative images that denied the residents of Brazil the social recognition they prized". ${ }^{8}$

\section{THE SLAVE OR “THE HANDS AND FEET OF THE SUGAR-MILL MASTER”,}

As discussed before, Portuguese colonial society in the Americas was organized around the division between freemen and slaves. In looking at the two extremes of the sugar-mill masters and their slaves it is possible to discern the ethical logic related to work that permeated social relations in the colony. Therefore, in view of what we already know about the sugarmill masters, it is necessary to compare the two forms of slavery present during the colonial period: the enslavement of Indians and that of Africans.

I6. João Luis Fragoso, "A nobreza da República: notas sobre a formação da primeira elite senhorial do Rio de Janeiro (séculos XVI e XVII)”, Topoi, I (2000), pp. 45-I 22.

17. Schwartz, Sugar Plantations, p. 25 I.

I8. Ibid., p. 272. 
To approach the theme, it is important to go back to its original Iberian roots. Among the laboratores, defined as dependants who dedicated themselves to production activities, the servant class stood out as the old slaves who had not been freed but placed in the domain and given land. ${ }^{19}$ The advance of the Reconquista, the "reconquest" of Muslim-dominated land in the Iberian peninsula, boosted the number of Moorish slaves in the hands of Christians, especially in Portugal. Domestic slaves remained important until the mid-thirteenth century; later they became the property of the king. It is necessary to point out, in our case, that in Portugal slavery remained an important labour relation and, as the Portuguese advanced across the southern Atlantic in the fifteenth and sixteenth centuries, it underwent a period of intensification.

The implantation and growth of the sugar-based economy in the Atlantic islands (Madeira and São Tomé) led to the strengthening of slavery as an institution and its steady redefinition as the prevailing labour relation in an activity geared to the market. When sugar production was introduced into Portuguese America, slavery naturally emerged as the ideal labour relation, already tested and approved in previous experiments carried out by the Portuguese themselves. The establishment of this labour relation as the structure at the basis of the colonial reality brought about the consolidation of a fundamental principle that permeates its entire history: the distinction between slavery and freedom. However, the racial element that permeated slavery in the New World created a new status criterion that dictated social life and ideology in the colony. Schwartz states that Brazilian society was the result of integration between the large plantations and the social principles that already existed in Europe, with slavery bringing about new principles of hierarchy, based on race, acculturation, and social condition. ${ }^{20}$

Initially, slavery in Portuguese America was based on the capture of Indians living on the Brazilian coast or in the hinterland. Eventually, the difficulties of maintaining the supply of such labour at the level demanded by the sugar industry, the demographic and social limits to the adaptation of the Indian population to the kind of work imposed by the sugar mills and plantations, and the progressively improved structure of the Atlantic slave trade led to a reduction in the number of Indians employed as slaves in Brazil and to an increasingly significant presence of Africans. Conflicts with the Jesuits and other religious orders who had taken on the task of converting the Indians also played a part here, and over time and with the advance of colonization, indigenous slavery was pushed to the fringes of the colonial system. ${ }^{2 \mathrm{I}}$ 
It is necessary to understand the disputes sparked by the enslaving of Indians and Africans. The debate that divided colonists and the regular clergy, especially the Jesuits, reveals other facets of the ideology of work that accompanied the establishment of Portuguese colonial society in America. Among the main points in the debate, I should like first to examine how the Jesuits viewed indigenous and African slavery in Brazil. The central role played by the Jesuits in the debate, and the importance of the Jesuits to different aspects of colonial life, not only religious life but the economy, education, and culture, justify the decision to concentrate on written records left by priests as they sought to spell out the work ethics that orientated their political actions.

\section{JESUIT VIEWS OF INDIGENOUS LABOUR}

As already mentioned, the Indians were the first option for the supply of compulsory labour in the first sugar plantations in Portuguese America. However, the debate that had been going on since the early advances of the Spanish among the Amerindian societies led the Catholic Church to take a stand, recognizing the human condition of the people and therefore definitively forbidding their enslavement. ${ }^{22}$ In 1537 Pope Paul III promulgated the papal bull Sublimus Dei, consolidating the Church's position and declaring that:

[...] the said Indians and all other people who may later be discovered by Christians, are by no means to be deprived of their liberty or the possession of their property, even though they be outside the faith of Jesus Christ; and that they may and should, freely and legitimately, enjoy their liberty and the possession of their property.

As a consequence, "nor should they be in any way enslaved; should the contrary happen, it shall be null and have no effect". ${ }^{23}$

The Jesuits arrived in Portuguese America in I 549, brought by the first Governor-General, Tomé de Sousa. Having been charged with the religious indoctrination of the Indians, the Jesuits soon saw themselves engaged in a dispute with the settlers, because, in observance of Sublimus Dei, the Jesuits were opposed to the enslavement of the Indians. They set up a system of settlements by which they organized the Indians in compliance with principles that sought to combine the way of life of the Indians with their acculturation, resulting from their evangelization.

22. A good discussion about the time Spaniards first arrived in America and found a completely different society can be found in Tzvetan Todorov, The Conquest of America: The Question of the Other (New York, 1984); and David Brading, The First America: The Spanish Monarchy, Creole Patriots and the Liberal State, I492-I867 (Cambridge, I99I), chs 3 and 4.

23. Quoted by Paulo Suess (ed.), A conquista espiritual da América Espanhola (Petrópolis, Rio de Janeiro, I992), pp. 273-275. 
In these settlements work played a central role in the process of adaptation of the Indians to the European way of life. However, the Jesuits were accused by the settlers of monopolizing the indigenous labour, and the Jesuits in turn responded by putting pressure on the Portuguese government to enforce the prohibition of Indian slavery.

As a result, in $\mathrm{I} 570$ the Portuguese Crown issued a law banning Indian slavery, except in the cases known as "the fair war" (guerra justa). According to that principle, only Indians hostile to Portuguese colonization could be made slaves after being captured. Alternatively, Indians who were made prisoners of other tribes and were rescued by expeditions of white settlers (resgate) could also be made slaves; after all, they had been rescued from death by white people. In I 595 and in I609 other laws of similar content were enacted, but the "fair war" and "rescue" principles remained as legitimate reasons for Indian slavery. It was only in the second half of the eighteenth century that Indian slavery was effectively banned, having survived in a few economically less dynamic parts of the colony.

According to Schwartz, three expedient measures were used by the Portuguese to make the Indians useful to the economy of the colony. ${ }^{24}$ The first was direct coercion by means of enslavement, transforming them into chattel slaves who produced goods for the market. If, on the one hand, the Portuguese Crown accepted the requests of the Jesuits to ban Indian slavery, on the other, their understanding of the economic needs of the settlers led them to maintain some loopholes in the law, allowing Indian slavery to go on by means of the fair war and rescue practices. The second measure was the settlements established by the Jesuits and other religious orders aimed at creating an indigenous peasantry, thus making the Indians fit in with European demands for their acculturation and de-tribalization, and that I regard as reciprocal labour within communities. As the creation of a peasantry came to nothing, the Jesuits then started to justify the continuation of their actions by emphasizing the supply of a military and labour force for the colonization enterprise. The third measure was the progressive integration of the Indians, who were individually incorporated as waged workers into an incipient labour market; in that case, Indians were transformed into market wage-earners.

During the time that they were in the Portuguese colony (I 549-1759), the Jesuits became deeply involved in the debate over captive labour, especially in relation to the Indians, and were instrumental in challenging the claims made by settlers to the Portuguese government. These disputes brought to the surface very important aspects of the way the Jesuits looked at the matter of work. 
From the first years of the colonization of Portuguese America, the clergy, especially the Jesuits, sought to emphasize the precedence of evangelization over mere economic interests. Serafim Leite mentions the first provincial superior of the Society of Jesus in Brazil, Father Manoel da Nóbrega, writing to the Governor General Tomé de Sousa in I 559:

These settlers fail to understand that the intention of our Holy King [D. John III], in his glory, was not so much to obtain gold or silver, or to people the land or build mills, or still bring wealth to the Portuguese in Portugal, as it was to glorify the Catholic faith and save souls. ${ }^{25}$

Work nevertheless played a central role in the routine of Jesuit settlements, for as we have seen their objective was to create a peasantry along the lines of European models, by way of the conversion and acculturation of the Indians. That resulted in a mixture of conversion and work.

The emphasis placed on work instigated conflicts with the settlers, who were equally interested in the low cost of the labour provided by Indian slavery. The conflict unleashed an acrimonious debate between representatives of the settlers and members of the clergy. The main argument of the settlers was that, since the Jesuits kept Indians working in the settlements, they were monopolizing their work and preventing the settlers from enjoying the economic advantages of so abundant and cheap a source of labour. This is how the Jesuits responded to the objections of the settlers, represented by Gabriel Soares de Sousa, that they were using the work of the Indians for their own benefit:

The only solution to this state is to have a lot of peaceful people in the settlements around the mills and farms because in this way there will be someone to fight the enemies, like the French, the English, and the Aimorés, who have done and are still doing so much evil, and someone to keep a tight rein on the black people from Guinea, who are so many and who fear no one else but the Indians. The only way to have this is by doing as His Majesty has ordered, although this order is not obeyed, that there should be no slaves in the same way as there are none in Peru. ${ }^{26}$

Starting in the sixteenth century, the debate over the nature of labour relationships to which the Indians could be subjected extended throughout the seventeenth century. The great intellectual figure among the Jesuits during that period was Father Antônio Vieira. He was born in Portugal in $\mathrm{I} 608$ and died in Bahia in $\mathrm{I} 697$ after a long and adventurous life during which he was recognized as the most prominent intellectual in the Portuguese empire. As highlighted by Alfredo Bosi, Vieira was an adviser to kings, confessor to queens, preceptor of princes, a diplomat in European courts, an advocate of the New Christians, a missionary in Maranhão and Pará, and

25. Quoted by Serafim Leite, Historia da Companbia de Jesus no Brasil (Rio de Janeiro, 1938), II, p. 4 .

26. Ibid., p. 92. 
finally the provincial superior of the Jesuits in Bahia. ${ }^{27} \mathrm{He}$ was an important advocate of the work of the Jesuits in Portuguese America and was a strong opponent of the claims made by the colonists.

Chased out and expelled from Belém do Pará together with other Jesuits because of their opposition to the enslavement of the Indians, Father Vieira delivered a sermon in Portugal in I662, before the queen: the "Sermon of the Epiphany", in which he stated his opposition to the settlers and defended the necessity of the presence of the clergy in converting and protecting the Indians. According to Vieira, without the priests "[W]hat would become of the poor, helpless Indians, the prey and scrap of all this war? What would become of the Christians? What would become of the catechumens [newly converted Christians]? What would become of the populace?" ${ }^{28}$ The work of the Jesuits made possible the conversion of these animal-like beings.

Those were the very barbarians or brutes who, deprived of the use of reason or sense of humanity, would relish human flesh, and from their skulls make cups to drink their blood, and from their bones flutes to celebrate with their guests. And these today are the beasts that, instead of taking our lives, welcome us and worship us, like the lions worshipped Daniel; these birds of prey that, instead of eating us, provide for us, in the same way as the crows provided for Elijah. ${ }^{29}$

Father Vieira pointed out the abject material poverty the Indians lived in to justify the efforts made by the Jesuits to convert them and discipline them for work:

[...] our stars perform their missions among poverty and helplessness, among disgust and misery and the helpless of the most uncultured of peoples, the most vile of peoples, the basest human beings of all that are born in this world. These people, who received so little from nature, for whom art and fortune made no effort at all, for whom a tree provides clothing, food, weapon, shelter, and a boat. ${ }^{3 \circ}$

Then, Vieira pointed to the racial component backing up the intentions of the settlers to enslave Indians: "But nothing is enough to curb the greed and tyranny of our defamers, as they claim [the Indians] are black, and therefore will have to be slaves." ${ }^{1}$ This statement reveals a surprising anti-racist discourse that also serves the purpose of highlighting the combination of social position and racial condition so characteristic of Brazilian colonial society:

If you despise me because you are white and I am black, do not think about colours; think about cause. Think that the cause of this colour is the sun, and you

27. Alfredo Bosi, Dialética da colonização (São Paulo, I992).

28. Antônio Vieira, Sermões (Porto, I950), II, p. 36.

29. Ibid., p. 40.

30. Ibid., p. 42.

31. Ibid., p. 43. 
will soon see how unfair your judgement is. The nations, some are whiter, others are blacker, because some are closer and other are farther away from the sun. And can there be worse inconsideration of understanding, or a most dreadful mistake of judgement among men than that I should be your master because I was born farther from the sun and you be my slave because you were born closer to it? ${ }^{32}$

However, the condemnation of those racial aspects of Indian slavery did not result in the condemnation of slavery as a labour relation. Vieira concluded his arguments by saying:

It is not my intention to ban slavery, What I want from this court, as is obvious and can be seen from my proposal, is that a committee of experts on the subject be formed, as was done before, and that the members declare, as it is declared by law - which is already registered - the reasons for "legal captivity". ${ }^{33}$

For Vieira, slavery was not the issue, given that it was the labour relation that sustained the economy and society and had been widely known since the beginning of Portuguese history. However, it would be up to the Portuguese government to draft and enforce clear principles governing licit and illicit captivity of the Amerindians.

As we shall see, it is important to emphasize that this definition of principles did not pertain to Africans, who were considered legitimate slaves. Anti-racism for Vieira was connected with the principles made explicit in Sublimus Dei. Indians were recognized as human beings with souls, and their enslavement was an obstacle to an efficient conversion. The enslavement of Africans was accepted as a natural way to save their souls to rescue them from that continent where conversion was impossible. In Vieira's view, race did not justify enslavement; conversion was the central aim that would be obtained through religious protection of the Indians and enslavement of Africans. In that sense, Vieira was not being contradictory, although his ideas were not shared by all the clergy.

That sermon exemplifies some of the ideas Vieira and the Jesuits had about the Indians; however, the place labour occupied in the project for society conceived by the Jesuits is not made very clear. That appears in a more explicit way in their sermons to black people, where it took the form of an ideological justification for the captivity of blacks.

\section{THE AFRICAN SLAVES: JESUIT VIEWS FROM VIEIRA TO ANTONIL}

The transition from the predominance of the Indians over the Africans in the composition of the slave workforce lasted half a century, starting 
from I 570 . During that time the Jesuits took a stand in relation to African slavery too. Their view was pragmatic, as the Jesuit order, little by little, became one of the leading masters if not the greatest owners of mills and farms in the Portuguese colony in America, and consequently of African slaves. They defended the principle that the enslavement of Africans was necessary in order to free both the blacks and the Indians. It would free the blacks because it would release them from physical death caused by war, and from spiritual death caused by paganism back home in Africa. Slavery would free the Indians because, with African captivity, it was possible to release the Indians from slavery and then complete their conversion.

Apart from that, it was generally understood that without African slaves it would not have been possible to provide efficient and reliable labour in Brazil, workers capable of leaving the Jesuits free to carry out their real mission, which was the catechization of the Indians and Africans and the education of the settlers. In I56I, for example, Father Manoel da Nóbrega declared:

Because we all admit that it is not possible to live without some [slaves] who will fetch wood and water for us and daily make the bread we eat, and do other chores that we cannot do for our brothers, especially because we are so few that we would no longer be able to take confessions and everything else [...] it seems that the Company must have [slaves] and acquire [them] exactly by the means allowed by the Constitutions, whenever possible, for our Schools and boys' homes. ${ }^{34}$

Moving in the same direction, in I 574 the attorney of the Portuguese Jesuit missions in Lisbon, Father Vale-Regio, informed Rome that the intention of avoiding slavery in Jesuit schools was possible only in Europe because "in India and in Brazil, where there are no other services but those performed by the slaves, there is no alternative but to use them". ${ }^{35}$

Once the moral dilemma over African slavery had been overcome within the Society of Jesus, throughout the seventeenth century the ideological role of the Jesuits became clear. Once again, Father Antônio Vieira was the leading figure in the construction of a discourse justifying African slave labour. Among a set of sermons delivered by him at different times during the seventeenth century, there were several dedicated to Our Lady of the Rosary, the patron saint of blacks. Generally addressed to the brotherhoods of the blacks, who organized themselves around the cult of the saint, the sermons were addressed to captive and freed Africans alike. They were, therefore, messages addressed directly to those who were the object of the preaching, so that they differed from the sermons for the Indians, since sermons to them were already addressed to a congregation of settlers or people in government. In other words, the 
sermons by Father Vieira acknowledged the Africans and their descendants as direct interlocutors, while the Indians received no such acknowledgement, since they were under the guardianship of the government or of religious orders.

Among the different sermons with Africans and their descendants as interlocutors, I would initially highlight Sermon XIV in particular, which was delivered in 1633 . The emphasis is placed initially on the argument that enslavement in Africa and exile to Brazil must be seen as an opportunity for conversion to the Christian faith, and hence a route to the door to paradise after death. It might have seemed like bad fortune at first, but it was really a miracle: "Oh, if the black people taken from the depths of their Ethiopia, and brought to Brazil, knew how much they owe to God and His Holy Mother; for this that might look like uprooting, captivity, and misery, but is in fact a miracle, and a great miracle." ${ }^{36}$

This miracle was expressed in the similarity between the fate of the slave working in the mill and Jesus Christ's fate, his crucifixion:

In the mill you are imitating crucified Christ $[\ldots]$ because you suffer in a very similar way to his suffering on the cross and all of His Passion. His cross was made of two logs, and yours in the mill is made of three [a reference to a new type of mill introduced in the seventeenth century]. In that place there was no shortage of sugar cane either, because it featured in the Passion twice: once serving as the sceptre of mockery and then as a source of the bile [sic] into which the sponge was dipped. Part of Christ's Passion was at night without sleep, and part in daylight without rest, and such are your nights and your days [a direct reference to the uninterrupted workload in the sugar mill during the cane harvest]. Christ naked and you naked; Christ with no food and you hungry; Christ abused in every way and you abused in every way. The manacles, the prisons, the whipping, the wounds, the offensive words, all this is part of your imitation that, if combined with patience, will gain you the right to martyrdom. ${ }^{37}$

According to Alfredo Bosi, in that sermon Father Vieira invoked an argument that reinforced both

[...] the discourse of sensitivity, which saw and expressed the agony of the slaves, and the discourse of understanding, capable of pointing to the iniquitous character of a society where men created by the same God the Father and redeemed by the same God the Son were set apart as masters and servants. ${ }^{38}$

The inequality so created appeared as the fall of humanity from an initial state in which there would be no masters and servants. The connection between work, in this case extremely painful and amounting to a great sacrifice, and the punishment of Adam and Eve's original sin was thus remade. 
In Sermon XXVII, Father Vieira again took up the idea of worthy sacrifice by elevating the condition of slavery to a divine level. Captivity would be only partial because while the body would be in agony the soul remained free:

So that, my black brethren, this captivity in which you suffer agony, however hard and rough it may be, or seem to be, is not total captivity, or for everything you are, is but half captivity. You are captive in that outer half, the vilest part of your beings, which is the body; in the other part, however, the inner and most noble part, the soul and all that belongs to it, you are not captive, you are free. ${ }^{39}$

The core of his argument consisted of enticing the minds of bondsmen with the prospect of freedom in the other world, in the world of God, that would come to them after death:

Because this great change of scene I am talking about will not be between you and them but, rather, between you and God, it will not be your masters who will serve you in Heaven, as it may well be that they will not get there, but God himself. It is God that will serve you in Heaven because you served Him on earth. ${ }^{4 \circ}$

Vieira took the paradigm of passion as a justification for captivity. However, as Alfredo Bosi pointed out, while the crucifixion of God appears in the gospels as an example of injustice and a farce, in Vieira the sacrifice of slavery was propitious, valid in its own right. ${ }^{4 \mathrm{I}}$ Therefore, the sermon assumed an ideological character, highlighting the inequality, suffering, and expropriation the slaves were subjected to, and at the same time advocating the need for them to suffer their fate as the only path leading to eternal glory.

What did those to whom Vieira directed his sermons think about them? We have little direct evidence about that. Literacy in colonial Brazil was very low, and few written sources have survived from the period. Indirect proof pointing to the acceptance of Vieira's arguments is the fact that he was continuously invited to speak by brotherhoods dedicated to Our Lady of the Rosary. Those brotherhoods were maintained by slaves and freed Africans and Afro-Americans, suggesting a widespread acceptance of Vieira's ideas among the most Catholicized part of the population.

This strand, followed by the discourse of the Jesuits about slavery, which solved the moral dilemma posed for them when slavery began in the sixteenth century in the Americas, paved the way for submission to a pragmatic discourse, orientated by the economic logic of the colonial enterprise. According to Bosi, the moral conscience expressed in Vieira was smothered by colonial mercantilism. ${ }^{42}$

39. Antônio Vieira, Sermões (Porto, I95 I), XIII, p. 340.

40. Ibid., XII, p. 362 .

4I. Bosi, Dialética da colonização, pp. I47-I48.

42. Ibid., p. I 54. 
That discourse is clearly expressed in a treatise published in Portugal in I7II, the pamphlet Cultura e opulencia do Brasil [Culture and Opulence in Brazil], signed by a certain André João Antonil. ${ }^{43}$ Just after publication, the work was banned by the Portuguese government as it contained details about the colony that were not supposed to fall into the hands of other European colonial states. The work was finally republished in the nineteenth century, and in the twentieth century it was discovered that the author was João Antônio Andreoni. Andreoni was an Italian Jesuit who had been invited to work with Father Vieira in Bahia at the end of the seventeenth century but disagreed with him about the conduct of the Jesuit enterprises in Brazil. At the end of his life, Vieira felt that he had been betrayed by his former pupil.

The work contains a very detailed account of the colony's economic activities. It refers to sugar and tobacco production, gold mines, and cattle raising and described the routes leading into the interior of the colony. It is a singular document about Brazil's past, as it contains, among other things, a detailed description of the workings of the sugar-cane mills. And it is precisely when it comes to sugar production that an ideological strand appears. According to Antonil, slavery appeared to be a given for sugar production. All the moral dilemmas about compulsory labour relations in the colony, which haunted the Jesuits during the previous centuries, disappeared in the light of efforts to objectify the slaves. Chapter 9, which deals with the slaves in the sugar mills, opens with the following concise statement: "The slaves are the hands and feet of the sugar-mill master, because without them in Brazil it is impossible to make, preserve, or expand the farms, of have a mill operating at all." 44

That conception can be associated with an attitude to work that emphasized the legitimacy of the direct exploitation of the worker by the owner of the means of production. So, when the sugar-production process is synthesized in chapter I 2 ("What sugar suffers from its birth to the moment it leaves Brazil") the author makes use of a discourse which associates the workers directly with the goods they produce. As Bosi points out, the chapter is distinguished for the use of passive verbs and metonymies, by which the tool replaces the worker, thus giving away how little the workers were valued in the result of their work. ${ }^{45}$ The sugar cane takes on the status of subject: it suffers and aches in order to be transformed into sweet sugar. It is interesting to compare this discourse with that of Father Vieira, in which the slave was the subject of suffering and his work compared to Christ's Passion. For Antonil, sugar cane played

43. I have used a recent Brazilian edition: André João Antonil, Cultura e opulência do Brasil (São Paulo, 1976).

44. Ibid., p. I 59 .

45. Bosi, Dialética da colonização, p. I74. 
the role of leading actor in the crucifixion scene, a clear denigration of the hands-on worker. Then, by the beginning of the eighteenth century, manual labour had been totally devalued and not even the suffering associated with slavery was considered a sure path to Heaven.

\section{FINAL CONSIDERATIONS}

Slavery survived in Brazil until I 888, when Brazil became the last country in the Western world to abolish it. Slave labour relations during the period of its use were fully ingrained in society, from the export sector to the urban domestic and service sector, as well as in small-scale production. The trade in slaves across the Atlantic remained active until I 850 , and its continuity was what guaranteed the deep penetration of the institution of slave labour. It was only towards the end that slavery started to lose strength, as reproduction rates among Brazilian slaves were rather low and the remaining contingents of bondsmen were concentrated in very few economic sectors.

The end of slavery meant that slaves were neglected and left to fend for themselves, there being no public policies to provide for those who were emancipated. Indeed, the main public policy on labour relations involved incentives to large-scale European immigration, which began in the I 870 s and peaked in the I890s. The policy had a racial component, since the immigration of white people was conceived of as a way to minimize miscegenation, and by reducing inter-racial mixing in Brazil to help minimize dependency on a "lazy population". Mass immigration brought about new free labour relations, needed for work in the quickly growing coffee industry in the state of São Paulo and, on a smaller scale, in the state of Minas Gerais. It was important too for the occupation of the south of the country. In fact, the free European worker was associated, in more economically dynamic regions, with the physical replacement of black or mestizo workers with white workers.

The other side of the coin of Brazilian slavery was the preservation of a work ethic identified with the so-called nobility of the land, the Portuguese style of colonization in Brazil. Until at least the first half of the nineteenth century, the Brazilian elite followed a pattern of behaviour by which their earnings from economic activities were compulsively converted into sterile investments, completely marginal to the logic of expanded capital reproduction. In a study on the behaviour of the mercantile elite of Rio de Janeiro for the fifty years between I 790 and I840, João Luis Fragoso and Manolo Florentino showed how income from agricultural exports was converted into urban real estate, or into means of generating revenues other than production industry. ${ }^{46}$ In other words,

46. João Luis Fragoso and Manolo Florentino, $O$ arcaísmo como projeto: mercado atlântico, sociedade agrária e elite mercantil no Rio de Janeiro, c.1790-C.I840 (Rio de Janeiro, I993). 
the sterilization of productive capital - or the pursuit of other ways of generating revenues outside the production sphere - reinforced the noncapitalist character of the production process.

That logic of reproduction of the mercantile elites calls to mind what was previously identified as the distinctive character of the "nobility of the land" who had settled the Portuguese colony in the Americas when sugar-cane planting was first adopted. The distinctive symbols of that social group, especially as they were deprived of noble lineage, were, first and foremost, the need not to work, especially not doing manual work, the ability to live within their means, and the capacity to occupy positions in public organizations, which guaranteed the exercise of political power. It is interesting, incidentally, to see how the undercurrents of work relationships still set the guidelines for the behaviour of important elements of the Brazilian elite even in times of great transformation, such as the beginning of the nineteenth century. The pattern of their behaviour can be seen as the complement to a work ethic that preserved slave labour and at the same time devalued the direct worker, encouraging the "ennobling" behaviour of the elites while promoting a workless lifestyle, the ultimate aim of those who longed to ascend the social ladder. 